\title{
Informing educators by examining the features of Russian- Tatar relation coverage by Tatar historians
}

\section{Impresionar a los educadores examinando las características de la cobertura de la relación ruso-tártaro por parte de los historiadores tártaros}

\author{
Aivaz Minnegosmanovich Fazliev \\ Ph.D. in History, Associate Professor at the Department of National History, the Institute of \\ International Relations, Kazan Federal University, Kremliovskaya St., 18, 420008, Kazan, Russian \\ Federation \\ ORCID: 0000-0001-6269-347X
}

Farit Nailovich Shakurov

Ph.D. in History, Associate Professor at the Department of National History, the Institute of International Relations; Kazan Federal University, Kremliovskaya St., 18, 420008, Kazan, Russian Federation, ORCID: 0000-0001-6617-8619

\section{Zavdat Salimovich Minnullin}

Ph.D. in History, Associate Professor at the Department of Historical and Social Science Education, Institute of International Relations, Kazan Federal University, Kremliovskaya St., 18, 420008, Kazan, Russian Federation

ORCID: 0000-0003-3559-3339

Ilsur Zakirzyanovich Nafikov

Ph.D. in History, Lecturer at the Department of General Turkic History of Istanbul University (Istanbul, Turkey). Istanbul University ORCID: 0000-0002-4575-619X

* Correspondence

Email: aivazik@mail.ru 
A special place belongs to the historical thought of the late 19th - early 20th centuries in the spiritual heritage of the Tatar people. In a short time, Tatar historians have achieved significant results in the reconstruction and study of the national past. Their successes were appreciated by Russian and European scholars and orientalists, and their unconditional leadership among other Turkic Muslims was generally recognized. The works by Sh. Mardzhani, R. Fakhrutdinov, G. Akhmarov, H. Atlasi, G. Gubaidullin are being republished today and are returned to the reader. Their work is being successfully studied, but there are no works where the formation and development of Tatar historical science at the end of the 19th - beginning of the 20th centuries would be considered specifically. A systematized study of the historical thought of the Tatars during the Jadid period, the determination of the characteristics, trends, and the directions of its development remains an urgent task of modern science. This scientific article examines the features of Russian-Tatar relation coverage by Tatar historians of the late 19th - early 20th centuries, reveals the information and analytical activities of censorship and its special attention to historical writings, contains an overview of little-known sources - popular editions and publications in time-based press, dated to the centenary of The Patriotic War of 1812 and the 300th anniversary of the House of Romanov, the authors of which, showing the commonality of the historical fate of Russians and Tatars, substantiated the thesis of "equal rights in a common Fatherland". The obtained analytical results are very effective in increasing the level of education of educators in this field.

Keywords: history, Tatar historiography, Russian-Tatar relations, censorship, historical anniversaries, equality of rights, Historical education

\section{Resumen}

Un lugar especial pertenece al pensamiento histórico de finales del siglo XIX y principios del XX en la herencia espiritual del pueblo tártaro. En poco tiempo, los historiadores tártaros han logrado resultados significativos en la reconstrucción y el estudio del pasado nacional. Sus éxitos fueron apreciados por los eruditos y orientalistas rusos y europeos, y su liderazgo incondicional entre otros musulmanes turcos fue generalmente reconocido. Las obras de Sh. Mardzhani, R. Fakhrutdinov, G. Akhmarov, H. Atlasi, G. Gubaidullin se vuelven a publicar hoy y se devuelven al lector. Su trabajo está siendo estudiado con éxito, pero no hay trabajos donde se considere específicamente la formación y el desarrollo de la ciencia histórica tártara a fines del siglo XIX y principios del XX. Un estudio sistematizado del pensamiento histórico de los tártaros durante el período Jadid, la determinación de las características, tendencias y direcciones de su desarrollo sigue siendo una tarea urgente de la ciencia moderna. Este artículo científico examina las características de la cobertura de la relación ruso-tártara por parte de historiadores tártaros de finales del siglo XIX y principios del XX, revela la información y las actividades analíticas de la censura y su especial atención a los escritos históricos, contiene una descripción general de fuentes poco conocidas: populares ediciones y publicaciones en prensa basada en el tiempo, fechadas en el centenario de La Guerra Patriótica de 1812 y el 300 aniversario de la Casa Romanov, cuyos autores, mostrando la similitud del destino histórico de rusos y tártaros, corroboraron la tesis de "Igualdad de derechos en una Patria común". Los resultados analíticos obtenidos son muy efectivos para incrementar el nivel de formación de los educadores en este campo.

Palabras clave: historia, historiografía tártara, relaciones ruso-tártaros, censura, aniversarios históricos, igualdad de derechos, Educación histórica 


\section{Introduction}

It should be noted that the formation of various trends of Tatar social thought in the late XIX early XX centuries was considered in a number of studies specifically devoted to this period or partially or completely including it. Meanwhile, it is obvious that without description of the general picture of historical thought development, there is no full-fledged history of social thought. In the second half of the XIX-th century radical changes are taking place in the development of Tatar historical thought, due to the reformist movement and the formation of an ethnic community of a new national type.

The former historical consciousness, turned into the past of the lost glory, was unacceptable for the awakening and reviving people. History, therefore, was not only one of the areas of scientific knowledge that the enlighteners advocated for the development. It was necessary to know the past in order to affirm the idea of ethnic unity and determine one's own historical and cultural place among other peoples. The task of reconstructing the national history has determined the main problems of the emerging historical science. The research begun by Sh. Mardzhani (1818-1889) was continued by his followers and successors R. Fakhrutdinov (1859-1936), H. Gabyashi (1863-1936), G. Akhmarov (1864-1911), H. Atlasi (1876-1938 ), A. Validi (1890-1970), G. Battalom (1880-1969), G. Gubaidullin (1887-1937), etc.

The historians of the early 20th century paid a great attention to the history of RussianTatar relations. But this was the topic where the greatest care had to be taken and censorship reckoned with. The features of its coverage common to Tatar historians in the works devoted to the national past before the fall of the Kazan Khanate can be simplified in the following theses. The Russians were the most restless neighbors of the Bulgars. The latter sought to maintain peaceful relations with them, preferring mutually beneficial trade to raids. Russia was under the cultural and political influence of the surrounding peoples and countries, but skillfully used the relations with them for its own strengthening. The patronage and connivance of the Horde to Moscow were the main reason for its rise, and soon, having united the Russian lands, it became a formidable force for the scattered Tatar khanates.

\section{Materials and Methods}

The methodology of this work is based on the doctrine of dialectical development and the principles of objectivity and historicism. The tasks of the study and the features of the studied material determined the choice of scientific knowledge specific methods. The methodological aspect of historicism principle, which reveals the dialectics of the phenomena of nature, society and science and requires their consideration from the point of view of genesis, formation and development with their inherent contradictions, is most fully revealed in the methods of comparative historical and concrete analysis. The first of them, which includes historical comparisons, makes it possible to study both historiographic facts belonging to a specific historical situation and the phenomena of historiography in their qualitative change, contributing to the clarification of historical thought development patterns. Specific analysis allows one to study historiographic phenomena, taking into account the conditions of their occurrence and mutual influence, constituting the most important condition for scientific analysis. We also used the periodization method, which follows from the principle of historicism, without which no historical research is possible. The purpose and tasks of the work, implying the systematization of the material, required the use of the systematic approach method. The method of logical analysis made it possible to reveal the peculiarities of trends, directions and stages in the development of historical thought, to generalize the results of the study theoretically.

Descriptive, chronological and problematic methods of the material presentation were used during the work on the article. 


\section{Results}

The translation commission of the Kazan educational district presented a review of Tatar textbooks, to the preparation of which the censorship - the Kazan temporary committee for press affairs - had a direct relationship. The irritation and displeasure of the professor of the Kazan Theological Academy Yakov Koblov, who prepared a report on the essays on civil history, is caused by the fact that in the "History of the Tatars" G. Battal notes the superiority of the Tatars over the Russians, and in the "Brief Bulgarian History" by G. Zabiri the chapter on the conquest of Kazan is called "Misfortune". It is important to note that, nevertheless, Y. Koblov admits the absence of distortion of historical facts by Tatar historians. His conclusions are disappointing: "Tatar authors seem to be still unable to get used to their position as Russian subjects and consider Russians as outsiders. The science is being studied in the depths of the state that is alien to the interests of Russian statehood" (Review of textbooks adopted for use in Tatar confessional schools (mektebs and madrasahs) and published for the most part during the past 3 years (1911-1913)). Meanwhile, the historical parallel, not bypassed by any Tatar historian who wrote about the Kazan Khanate, explained the reasons for the Tatars' rejection of Russian reality (the evidence of censorship persecution did not allow speaking about these reasons directly). They stressed that the Kazan rulers did not allow encroachments on the faith and customs of the non-Muslim and pagan peoples of their country, who had equal rights with Muslims (Akhmarov, 1910; Battal, 1916).

The relationship between the Russian state and the Tatars was to become one of the main subjects of research devoted to national history after 1552. But, firstly, the main goal of Tatar historians was to recreate the past before the fall of the Kazan Khanate - "a true, independent history", and most of the works covered this period only. Secondly, the censorship left no hope for an objective reflection of the Tatars position in Russia. Shigabutdin Mardzhani, narrating in the second part of "Mustafad al-akhbar fi akhvali Kazan va Bulgar" (Mardzhani, 1900) about the history of mosques, madrasahs and the activities of the clergy, reveals the most important phenomenon of Tatar history after the loss of independence, when spiritual institutions became a social institution that united the people, but almost does not apply to other topics. At the same time, the manuscript submitted for publication contained a description of the Tatars' performance, led by Ishbulat, against the actions of the notorious missionary Luka Kanashevich, various facts of colonial oppression of non-Russian peoples were reported, the biography of Imam Shamil was given, and everything was deleted by the censor Smirnov (Gaziz, 1915). Murad Ramzi's "Talfik alakhbar va talkikh al-asar fi vakayig Kazan va Bulgar va muluk at-Tatars" was prohibited (Ramzi, 1908), where the history of the Tatars after the fall of Kazan was systematically presented in one of the chapters for the first time. Rashid Ibragimov, who openly wrote about the national and religious oppression of Muslims in Russia, published his book abroad (Ibragimov, 1895).

At the beginning of the second decade of the last century, in the midst of the persecution against the representatives of the intellectual elite of Russian Muslims, which began under the banner of the struggle against pan-Islamism-pan-Turkism and the "fifth column" of Turkey, Tatar public thought turned to the theme of a "common homeland". It was thoroughly covered in literature and journalism, where a retrospective of historical facts begins, confirming that the Tatar people defended the independence of a common fatherland alongside the Russians during the years of severe trials for Russia.

Almost all references to such pages of the past were timed to the celebrations dedicated to the centenary of the Patriotic War of 1812 (August 1912) and the three hundredth anniversary of the House of Romanovs (February 1913). In fact, the anniversary celebrations were used as a very opportune occasion to give a response to attempts to accuse the Tatars of striving to secede from Russia and, proving the thesis of the common homeland, to demand equal rights. Otherwise, everything would be limited to routine events and obligatory loyal publications in the press. It 
should be especially noted the anniversary of the war of 1812 , which was accepted by the Tatars as their national holiday and passed in an atmosphere of spiritual uplift, and sincere expression of patriotic feelings to complete surprise for the official authorities. Could they have imagined that the Tatars, for example, would organize literary and musical evenings in the Kazan gardens, where Tatar and Russian songs would be performed, the verses of Tatar and Russian poets would sound?

Reflection of the theme of "common homeland and equal rights" in literature and journalism was examined in detail by M. Magdeev in the monograph "The Social Roots of Talent" (Magdeev, 1990). We will focus on the anniversary historical publications and some publications in the Tatar periodicals of that time.

The jubilee historical brochures that we identified, and issued for the centenary of the Patriotic War, represent the translations of similar Russian publications ("1812 in Russia" by N. Mikhnevich; "Blessed Tsar Emperor Alexander I" by N. Duchinsky) or compilations on their basis ("History of the War for the Fatherland, or for our native land, in 1812" by M. Imanaev). The censor Arkady Yemelyanov was perplexed that the translators did not even bother to smooth out the peculiarities of Russian originals, completely imbued with religious and Christian sentiments, which, in his opinion, only repelled the Muslim reader (Criticism and bibliography, 1913).

The publications dedicated to the 300th anniversary of the House of Romanovs and also compiled on the basis of official popular brochures, described the events of the Time of Troubles and the election of Mikhail Romanov to the kingdom, set out the noble deeds of the representatives of the ruling dynasty, noting the manifestations of royal mercy to Muslims. For example, "Time of Troubles in Russia and the election of the Romanov dynasty to the Russian throne", prepared by the publishing house "Belek" of Orenburg, "300 years ago" by Avyrgazi, and "300th anniversary of the reigning by the House of Romanovs" by M. Imanaev. One of them - "Muslims in the Time of Troubles and their participation in the election of Mikhail Fedorovich Romanov to the throne" by A. Validi - was an independent research based on Russian and Tatar sources and Russian historical literature.

Proving the equality of the rights of Tatars and Russians in the past, Validi refers to the panegyric Boris Godunov from the "Collection of Chronicles" Kadyr-Ali-bek ("Praise to Boris") and to the official documents on the election of Mikhail Romanov, where several Tatar surnames were indicated. The historian writes that during the elections of the new dynasty, "the Tatars were full citizens of the common state and stood in the same ranks with the Russians" (Validi, 1913). But then the tsars forgot about the services they rendered, and the Tatars became powerless.

Among the jubilee issues of Tatar newspapers and magazines, the most notable was the special issue of the magazine "Ang" ("Consciousness") (Consciousness, 1913). Its main publication - "The History of the Romanov Dynasty and the First Tsar Mikhail Fedorovich Romanov" presented by G. Karam - is written the spirit of the official anniversary editions. There are also the translations from Russian historical stories "The Innocent Martyr Mikhail Nikitich Romanov" and "The Feat of Susanin". The issue is illustrated with portraits of the Romanovs (the requirement of the Kazan Press Committee). For us, the article "The Accession of the Romanovs and the Tatars" by Gaziz Gubaidullin is of interest.

He notes that the oppression and eviction of the Tatars, the ruin of Kazan were committed by the kings of the Rurik-Kalita clan, whom the people did not choose. The Romanov dynasty was elected by all the peoples of Russia at the most representative Zemsky Sobor. Referring to the "Collection of State Letters and Treaties" and the works of Russian historians, G. Gubaidullin shows the participation of the Tatar aristocracy in the Zemsky Sobor: "... thus, we can definitely say that this dynasty was chosen by us, it is our dynasty" (Gaziz, 1913). The historian emphasizes that the Tatar regiments fought for Russia as for their Motherland during the war against the intervention. 
Both Validi and Gubaidullin write not about the former equality of the entire Tatar people, but about cooperation between the Russian elites and the Tatar feudal lords close to them or included in their circles. Should these works be viewed as an expression of the desire of the Tatar possessing classes to participate in power, as was stated in Soviet historiography? There is no good reason for this. Compiled as commemorative publications, they were supposed to reflect the events of Mikhail Romanov's election to the throne, in which only the representatives of the Tatar elite could participate. The uncensored sincerity of some of the statements by these authors is doubtful, knowing their attitude to the history of Russian-Tatar relations in other works, including postFebruary. Be that as it may, we have to admit that the substantiation of the thesis of "equal rights in a common homeland" in historical publications on the occasion of anniversaries was inferior in evidence and, most importantly, in the impact on the reader during this topic coverage in fiction. Here is how the poet Gabdulla Tukai wrote about the past of the Tatars in Russia:

Breaking down, that melody will tell what the Tatar soul feels. How rock crushed us for those three hundred years, what a pity we lived.

How much suffering our people endured; how many tears were shed (from the poem "National motives") (Tukay, 1909).

On the land of Russia, we are noticeable, we have traces. In its story, we are a spotless mirror. They lived with the Russians, singing songs, exchanging language, vocabulary, customs and traditions.

And will the end of this historical union come?

We were born as if strung on a thread. On the battlefield we are stronger than the tigers, in days of peace we work harder than horses.

Should this people be powerless?

We have enough rights to equality in the common Motherland!

(from the poem "Hopes of the people in connection with the great anniversary") (Tukay, relations.

So, the poet's genius vividly and accurately revealed the dialectics of Russian-Tatar

\section{Discussions}

The chronological framework of the study covers the period from the end of the 19th century until February 1917. After the February revolution, the development of historical science took place in changed socio-political conditions and requires special consideration. The content of the emerging historical science was determined by the tasks of national renewal. The creation of the scientific history of the Tatar people determined its main problems. Another direction was made up of the studies that covered the history of Islam from the standpoint of reformism. Within the framework of a nascent science, one should also consider the works devoted to the development of historical knowledge among the Tatars, and the beginning of methodological problems of history development. It is more difficult to determine the rest of the directions of historical thought. Diversity and mosaicism were one of the characteristic features of the historical literature of that period. The formation of science was a contradictory and complex process, and in this case, we should talk about the development of other areas of historical knowledge, the genesis of other directions of science. The source base was made up of Arabic publications in the Tatar language related to the indicated period and of the publications in the national periodicals, dedicated to various areas of historical knowledge (including foreign authors). For example, the ethnogenetic concept of Mardzhani and its role in the formation of the historical consciousness of the Tatars are considered in the works by D. Iskhakov and foreign historians Y. Shamiloglu (USA) and G. Emelyanova (Great Britain) (Shamiloglu, 1991; Emelyanova, 1999). And the discussion around the ethnonym in the journal "Shura" and the position by R. Fakhrutdinov on this issue was 
described with a separate paragraph in the book of the Turkish historian I. Turkoglu (Türkoglu, 2000).

\section{Conclusion}

In the studies on national history, the division of the history of the Tatars into two main periods, proposed by S. Mardzhani, has become generally accepted - before the fall of Kazan and as the part of Russia. The past before the fall of the Kazan Khanate was considered "a real, independent history," and most of the works were devoted only to this period. And if a relatively objective reflection of the first period was possible even under the conditions of restrictions, then the censorship did not leave any hope for the actual position exposition by the Tatars after 1552 . Nevertheless, the Tatar historians highlighted and revealed the role of Islam and the Muslim clergy in preservation and the unification of the people after the loss of independence. The unity of the historical fate of the Turkic communities conquered by Russia was considered as a decisive factor in ethnic consolidation.

A characteristic feature of works on the history of the Tatar people was the coverage of the common Turkic past. Historians have not been able to avoid the Turkic antiquity idealization - a quality inherent in the historical consciousness of the national revival period, when the desire for a better future leads to a search for greatness in the past. Showing the vicissitudes of the political history of the Turks and Tatars, they emphasized the need for intra-ethnic and inter-Turkic unity.

Through historical parallels, historians strove to show that an encroachment on faith and national rights is the reason for the Tatars' rejection of Russian reality. A retrospection of historical facts begins in literary works and historical publications dedicated to the centenary of the Patriotic War of 1812 and the 300th anniversary of the House of Romanovs, in the midst of a new wave of repressions against Muslims, proving that during the years of severe trials, the Tatars defended the independence of the common fatherland along with the Russians. The jubilee celebrations are essentially used to respond the attempts to accuse the Tatars striving to secede from Russia and to demand equal rights, proving the common homeland thesis.

\section{Conflict of Interests}

The authors declare that the provided information has no conflicts of interest.

\section{Acknowledgements}

The work is performed according to the Russian Government Program of Competitive Growth of Kazan Federal University.

\section{References}

Akhmarov, G. (1910). History of Kazan in Tatars. Kazan, 32-33.

Battal, G. (1916). History of the Tatars in Tatar language. Kazan, p. 126.

Consciousness (1913). in Tatar language, 5.

Criticism and bibliography. (1913). Foreign review. Kazan, Book. 3. pp. 219-240.

Emelyanova, G. (1999). On the issue of the national self-identification of the Volga Tatars in the late 19th - early 20th centuries: Tatarism, Turkism and Islamism. World of Islam, 1-2, 111.

Gaziz, G. (1913). Accession of the Romanovs and the Tatars in Tatar lang. Consciousness, 5, 8082.

Gaziz, G. (1915). Historical works of Mardzhani / in Tatar language. Mardzhani. Kazan, 333-358.

Ibragimov, R. (1895). Morning star / in Turkish lang. Istanbul, 53 p.

Magdeev, M.S. (1990). The social roots of talent. Kazan: KSU Publishing House, 66-89.

Mardzhani, Sh. (1900). Information drawn to the history of Kazan and Bulgar / in Tatar language. Kazan, Ch. 2. 368 p. 
Ramzi, M. (1908). Collection of news and monuments about the events in Kazan and Bulgar and about Tatar rulers: in 2 volumes / in Arab. lang. Orenburg, 1, 729 p.; V. 2.539 p.

Review of textbooks adopted for use in Tatar confessional schools (mektebs and madrasahs) and published for the most part during the past 3 years (1911-1913) // Foreign Review. Kazan, 1916. V. 2. No. 2/3. pp. 197-249.

Shamiloglu, Y. (1991). Formation of the historical consciousness of the Tatars: Shigabutdin Mardzhani and the image of the Golden Horde. Tatarstan, 10, 21-27; Iskhakov D. Problems of the Tatar nation formation and transformation. Kazan, 1997. pp. 71-73.

Tukay, G. (1909). National motives / in Tatar lang. Literature. Kazan, p. 8.

Tukay, G. (1913). Hopes of the people in connection with the great anniversary / in Tatar lang. School, 1, p. 1.

Türkoglu, I. (2000). Rizaetdin Fakhretdin as one of the leaders of the movement for the Turks of Russia renewal / in Turkish lang. Istanbul, 228-239.

Validi, A. (1913). Muslims in the Time of Troubles and their participation in the election of Mikhail Fedorovich Romanov to the kingdom / in Tatar lang. Kazan: Sabakh, 68 p. 